\title{
Sustained viral load and late death in Rag2-/- mice after influenza A virus infection
}

\author{
Haiya $\mathrm{Wu}^{1}$, Verena Haist ${ }^{2}$, Wolfgang Baumgärtner ${ }^{2}$, Klaus Schughart $^{1 *}$
}

\begin{abstract}
The importance of the adaptive immune response for secondary influenza infections and protection from a lethal challenge after vaccination has been well documented. However, some controversy still exists concerning the specific involvement of B and T cells during a primary infection. Here, we have followed the survival, weight loss, viral load and lung pathology in Rag2 ${ }^{-1-}$ knock-out mice after infection with influenza A virus (H1N1). Infected wild type mice initially lost weight early after infection but then cleared the virus and recovered. Rag $2^{-1}$ mice, however, showed similar weight loss kinetics in the early stages after infection but weight loss continued post infection and culminated in death. In contrast to wild type mice, Rag $2^{-1-}$ mice were not able to clear the virus, despite an increased inflammatory response. Furthermore, they did not recruit virus-specific lymphocytes into the lung in the later stages after infection and exhibited sustained pulmonary lesions.
\end{abstract}

\section{Findings}

The essential role of the adaptive immune system for a secondary protective immune response after primary infection or vaccination has been demonstrated previously (for review, e.g. [1,2]. In primary infected mice, depletion of CD8 and NK cells caused increased death [3] whereas depletion of CD4 cells resulted in delayed viral clearance but survival of infected mice [4]. $\beta 2 \mathrm{~m}$ knock-out mice, which are deficient in CD8 cells survived infection and cleared the virus [5]. However, the specific role of B cells during primary infection is still somewhat controversial. Mice lacking mature B cells $\left(\mu \mathrm{MT}^{-/-}\right)$were more susceptible to virus infections whereas $\mu \mathrm{MT}^{-1-}$ mice primed with a sub-lethal dose survived a subsequent infection [6]. Although mice lacking both CD8 and B cells died after influenza infections $[7,8]$, mice lacking CD4 and B cells survived [9]. However, others reported that mice deprived of antibodies and mature B cells [10] or IgM depleted mice [11] survived influenza infections. More recently, Lee et al. [12] showed that mice lacking B cells succumbed to influenza H1N1 (PR8) infection despite the infiltration of a larger number of CD8 cells. Mice lacking CD4 cells $\left(\mathrm{Cd} 40^{-/-}\right.$and class $\mathrm{II}^{-/-}$mice $)$, however, recovered from

\footnotetext{
* Correspondence: klaus.schughart@helmholtz-hzi.de 'Department of Infection Genetics, Helmholtz Centre for Infection Research and University of Veterinary Medicine Hannover, Inhoffenstr. 7, D-38124 Braunschweig, Germany
}

infection similar to wild type mice [12]. SCID mice (Prkdc deficient) lacking B, T and NK cells [13] succumbed to infection but could be rescued by passive transfer of influenza-specific antibodies [14]. Rag1 ${ }^{-1 /}$ and $R a g 2^{-1-}$ mice are defective in the recombination machinery which is required for development of both $\mathrm{B}$ and $\mathrm{T}$ cells but are able to produce NK cells [15-17]. No other innate immune cells are affected by these mutations. $\operatorname{Rag}^{-1-}$ mice died between day 10 and 12 after primary infection with influenza A virus, and injection of natural IgM antibodies could delay death for two more days [18]. Rag $2^{-/-}$mice have so far only been tested in a secondary influenza infection challenge assay after vaccination [19] but were not studied in a primary infection challenge model. Therefore, the aim of the present study was to investigate the combined effect of the absence of $\mathrm{B}$ and $\mathrm{T}$ cells during a primary influenza A infection in $\mathrm{Rag}^{-/-}$mice.

Our findings showed that at early stages after a primary infection with influenza A virus (PR8, H1N1) wild type female mice (C57BL/6J) started to lose weight soon after infection (day 2 at the high, day 5-6 at the low dose of infection) and exhibited a maximum weight loss at about 6-7 days post infection (p.i.). After day 7 wild type mice recovered and started to re-gain their body weight (Figure 1A). $\operatorname{Rag} 2^{-/-}$mice exhibited a similar weight loss as wild type mice until day 6-7. However, from day 7 p.i. on, they did not recover but continued 


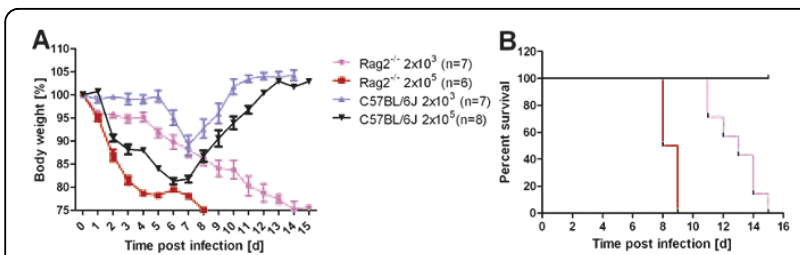

Figure $1 \mathrm{Rag}^{-/-}$female mice lost weight and died at late time points after primary infection. Female wild type or Rag2 $2^{-1}$ mice were infected with $2 \times 10^{3}$ or $2 \times 10^{5} \mathrm{FFU}$ of influenza A virus PR8 (H1N1) as described [20] and weight loss (A) and survival (B) was recorded for the next 16 days. In addition to mice that were found dead, mice with a weight loss of more than $25 \%$ of the starting bodyweight were euthanized and recorded as dead.

losing weight until they died (Figure 1A). Survival curves showed that wild type mice did not die from the infection at the two infection doses tested whereas Rag2 $2^{--}$ mice died at 8-9 days p.i. after receiving the high dose and between 11 and 14 days p.i. after the low dose of infection (Figure 2B). The kinetics of death for Rag2 $2^{--}$ mice is very different from that observed in highly susceptible inbred mouse strains [20] which die within the first 4-7 days. We conclude from these studies that the innate immune response, although it may not be completely normal in $\mathrm{Rag} 2^{-/-}$mice, works as efficiently as in wild type mice to control viral replication and spread at early stages of the infection. However, after about day 8 , the adaptive immune response is required to finally clear the virus and resolve the infection. The kinetics of the weight loss and death are very similar to the detrimental effect observed for B cell deficient mice [12]. Our results thus corroborate these observations, namely, that B cells represent an essential component of the adaptive immune response for efficient virus clearance and host survival in the course of a primary infection.

To evaluate a possible sex-specific effect, male wild type or $\mathrm{Rag}^{-/-}$mice were infected with PR8 virus. All

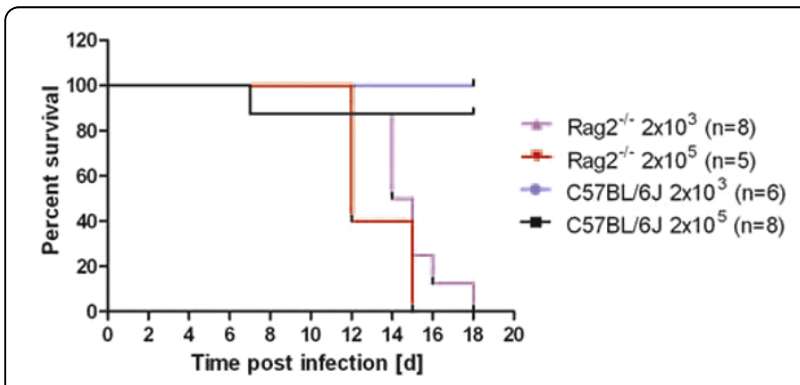

Figure $2 \operatorname{Rag2}^{-1-}$ male mice exhibited a similar response as female Rag2 $^{-1-}$ mice. Male wild type or Rag $2^{-1}$ mice were infected with $2 \times 10^{3}$ or $2 \times 10^{5} \mathrm{FFU}$ of influenza A virus PR8 (H1N1) and weight loss and survival was followed for the next 20 days. In addition to mice that were found dead, mice with a weight loss of more than $25 \%$ of the starting bodyweight were euthanized and recorded as dead. infected male $\operatorname{Rag} 2^{-/-}$mice died between day 12 and day 18 after infection whereas wild type mice survived. Only one wild type mouse died after infection with the high dose infection (Figure 2). Thus the sex of $\mathrm{Rag}^{-1-}$ mice does not influence their susceptibility to infection.

Viral load was studied in wild type and $\mathrm{Rag}^{-/}$mice as described [20] after infection with $2 \times 10^{3}$ FFU of influenza A virus PR8 (H1N1). Whereas wild type mice were able to clear the virus by day 8 after infection, $\operatorname{Rag} 2^{-/-}$ mice did not reduce viral loads from infected lungs at any time before death (Figure 3 ).

Furthermore, virus distribution in infected lungs was evaluated by immunohistochemistry using antibodies against the virus nucleoprotein (NP). Female wild type or $\mathrm{Rag}^{-/-}$mice were infected as described [20] and lung tissue sections were prepared from three mice per group and stained for viral NP protein (using anti-influenza NP polyclonal goat antibody, Virostat, Portland, USA, as described [21]). For each mouse, five slides were evaluated. NP-positive cells could be detected in the bronchiolar and alveolar regions at 2, 4 and 6 days p.i. in both wild type and $\mathrm{Rag}^{-{ }^{-}}$mice in bronchiolar and alveolar regions (Figure 4). However, at 8 and 10 days p.i. no $\mathrm{NP}$-positive cells were detected in wild type mice whereas NP antigen was still detectable in $\mathrm{Rag}^{-/-}$mice (Figure 4). These results corroborate the observations made for viral loads in the whole lungs, namely that $\mathrm{Rag}^{-/-}$mice were not able to clear the virus.

Wild type and $\mathrm{Rag}^{-/-}$mice differed markedly in the severity and type of pulmonary lesions at later time points after infection (Table 1 and Figure 5). Histological lesions were observed in variable proportions and severity in bronchial epithelial necrosis, neutrophilic

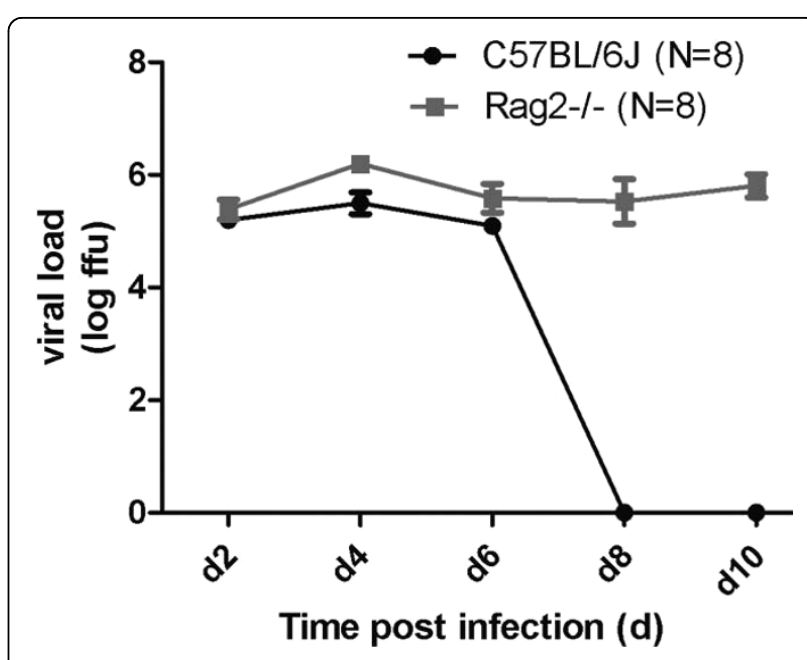

Figure $3 \mathrm{Rag2}^{-/-}$mice were not able to clear viral infection. Female wild type or Rag2 ${ }^{-1}$ mice were infected with $2 \times 10^{3} \mathrm{FFU}$ of influenza A virus PR8 ( $\mathrm{H} 1 \mathrm{~N} 1)$ and viral load in the lung was determined by focus forming assay [20]. 


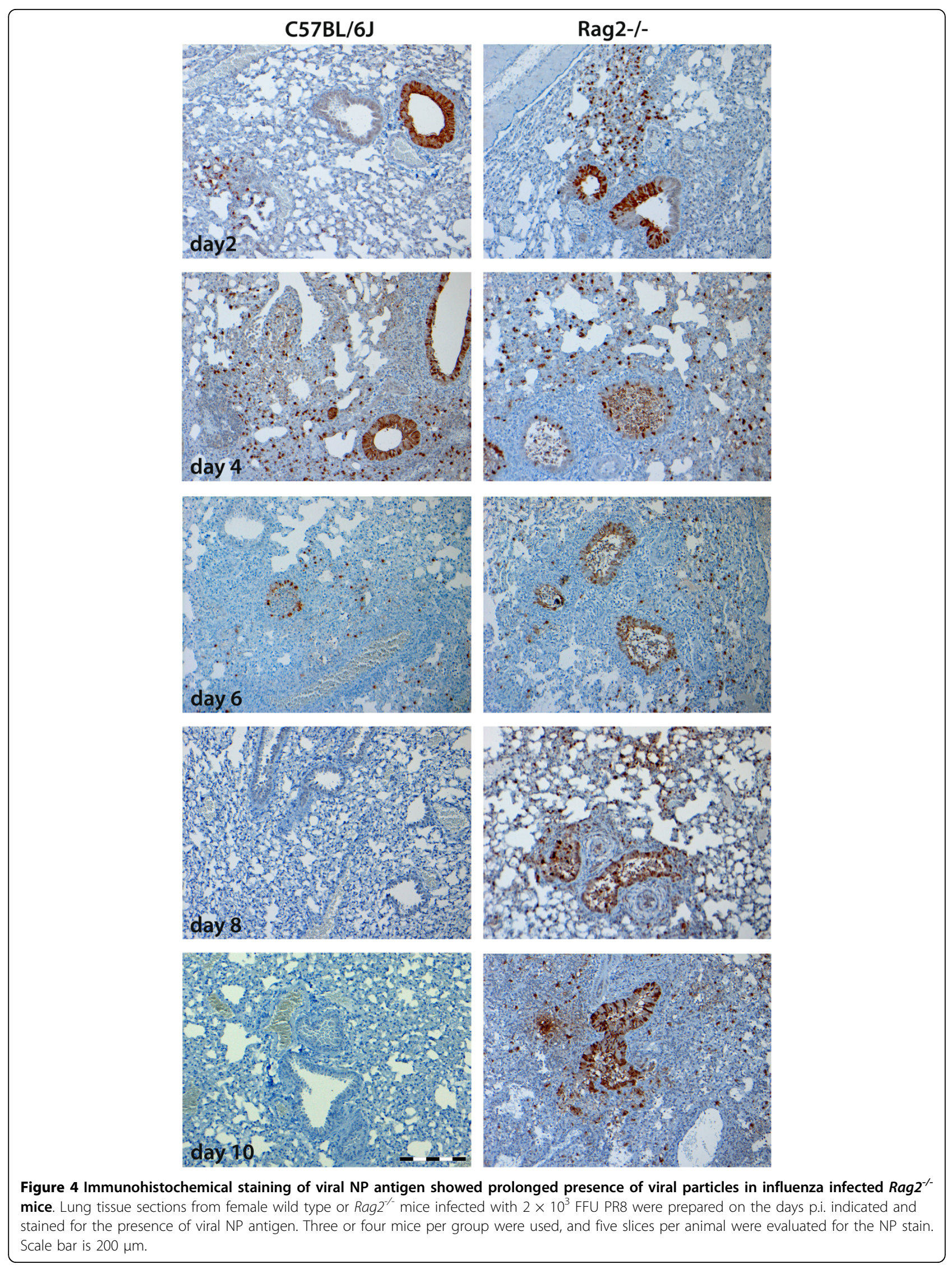


Table 1 Continuous pulmonary damage and inflammatory response in influenza infected $\operatorname{Rag2}^{-/-}$mice

\begin{tabular}{|c|c|c|c|c|c|c|c|}
\hline Group & $\begin{array}{l}\text { Percentage of } \\
\text { affected lung } \\
\text { parenchyma }\end{array}$ & $\begin{array}{c}\text { Severity of } \\
\text { necrosis in } \\
\text { affected bronchi }\end{array}$ & $\begin{array}{l}\text { Necrosis } \\
\text { of alveolar } \\
\text { walls }\end{array}$ & $\begin{array}{c}\text { Hyperplasia } \\
\text { of type } 2 \\
\text { AEC }\end{array}$ & $\begin{array}{c}\text { Lymphocytic } \\
\text { infiltrates around } \\
\text { bronchi and vessels }\end{array}$ & $\begin{array}{l}\text { Infiltrating } \\
\text { neutrophils in } \\
\text { airways and } \\
\text { interstitium }\end{array}$ & $\begin{array}{c}\text { Histiocytic infiltrates } \\
\text { in alveolar walls and } \\
\text { lumina }\end{array}$ \\
\hline $\begin{array}{c}\text { B6 } \\
\text { PBS }\end{array}$ & $<5 \%$ & 0 & 0 & 0 & 0.2 & 0 & 0 \\
\hline $\begin{array}{c}\text { B6 } \\
\text { day2 }\end{array}$ & $6 \%$ & 1.8 & 1.8 & 0 & 1.4 & 1.6 & 1.6 \\
\hline $\begin{array}{c}\text { B6 } \\
\text { day4 }\end{array}$ & $12 \%$ & 4 & 3 & 0.2 & 2.8 & 1.8 & 2.4 \\
\hline $\begin{array}{c}\text { B6 } \\
\text { day6 }\end{array}$ & $50 \%$ & 3.6 & 3.2 & 1 & 4.6 & 1.2 & 3.6 \\
\hline $\begin{array}{c}\text { B6 } \\
\text { day8 }\end{array}$ & $34 \%$ & 2.6 & 2 & 1.8 & 4 & 0.4 & 3.2 \\
\hline $\begin{array}{c}\text { B6 } \\
\text { day10 } \\
\end{array}$ & $24 \%$ & 2 & 1 & 3.2 & 4.4 & 0.2 & 3.2 \\
\hline $\begin{array}{l}\text { Rag2 } \\
\text { PBS }\end{array}$ & $<5 \%$ & 0 & 0 & 0 & 0.2 & 0 & 0 \\
\hline $\begin{array}{l}\text { Rag2 } \\
\text { day2 }\end{array}$ & $<5 \%$ & 1 & 1.6 & 0 & 1.4 & 1.2 & 0.6 \\
\hline $\begin{array}{l}\text { Rag2 } \\
\text { day4 }\end{array}$ & $18 \%$ & 3.2 & 2.2 & 0.4 & 1.2 & 2.4 & 3.2 \\
\hline $\begin{array}{l}\text { Rag2 } \\
\text { day6 }\end{array}$ & $60 \%$ & 4.2 & 2.8 & 1 & 0.6 & 3.6 & 4 \\
\hline $\begin{array}{l}\text { Rag2 } \\
\text { day8 }\end{array}$ & $18 \%$ & 3.6 & 2.8 & 1.4 & 0.4 & 3.2 & 2.2 \\
\hline $\begin{array}{l}\text { Rag2 } \\
\text { day10 }\end{array}$ & $44 \%$ & 3.4 & 3.2 & 3 & 0 & 4.4 & 3.6 \\
\hline
\end{tabular}

Semi-quantitative scoring of pulmonary lesions and immune cell infiltrates (median value of each group, 3 or 4 mice per group, 5 successive sections per sample).

Lung tissue sections from female wild type or Rag ${ }^{-1-}$ mice infected with $2 \times 10^{3}$ FFU PR8 were prepared on the days p.i. indicated, stained with hematoxylin and eosin and evaluated for the indicated features by a semi-quantitative grading system with the scores of 0 to 5 representing the degree of severity as follows: $0=$ no lesion; 1 = minimal; $2=$ mild; 3 = moderate; 4 = severe; $5=$ marked. Abbreviations: AEC, alveolar epithelial cell; B6, C57BL/6J mice; PBS, mice treated with Phosphate Buffered Saline as non-infected control; Rag2, Rag2 ${ }^{-1}$ mice.

infiltrates in airways, lymphocytic peribronchial and perivascular infiltrates, histiocytic infiltrates in alveolar walls and lumina, alveolar necrosis, and hyperplasia of type 2 alveolar epithelial cells. Similar percentages of airways were affected in wild type and $\operatorname{Rag} 2^{-/-}$mice after infection. In addition, the degree of cell necrosis was similar in both strains after 2 to 8 days p.i. in affected bronchial epithelium and alveolar walls. However, at day 10 after infection necrosis was considerably more severe in $\operatorname{Rag}^{-/-}$mice (Table 1, Figure 5F). Furthermore, lymphocytic peribronchial and perivascular infiltrates could be observed in wild type mice at all times after infection (Figure 5A, C, E), beginning at day 2 and reaching high levels at days 6,8 and 10 p.i. In $\operatorname{Rag} 2^{-/-}$mice, the amount of lymphocytic infiltrates around bronchi and vessels was similar to wild type at day 2 , but was much less at days 4,6 and 8 p.i. and absent at 10 days p.i. (Table 1, Figure 5D, F). These results showed that in $\mathrm{Rag}^{-/-}$mice lymphocytes of the innate immune response were recruited to the infected lungs at early time points after infection but specific lymphocytes were absent at later time points. Neutrophilic infiltrates were present in wild type mice at all times after infection. In $\operatorname{Rag} 2^{-/-}$mice the number of neutrophils was comparable to wild type mice at days 2 and 4 but was much higher at days 6,8 and 10 p.i. (Table 1 , Figure 5D, F). These observations indicate that in $\operatorname{Rag} 2^{-/-}$mice the continued presence of infectious virus in the lung stimulated a constant inflammatory response leading to a continuous and later increasing infiltration of inflammatory immune cells. It is important to note that despite the increased inflammatory response, $\mathrm{Rag} 2^{-/-}$mice were not able to clear the virus suggesting that for viral clearance and survival, a virus-specific response of the adaptive immune system is essential.

Our observations corroborate the results obtained by for $R a g 1^{-/-}$mice with respect to death at late time points after primary influenza virus infection [18]. In addition, we show here extended viral loads, sustained pulmonary lesions and absence of virus-specific lymphocyte infiltrations in $\operatorname{Rag} 2^{-/-}$deficient mice.

In conclusion, the present results strongly suggest that the innate immune response in $\mathrm{Rag}^{-/-}$knock-out mice, although it may not be completely normal, works as 


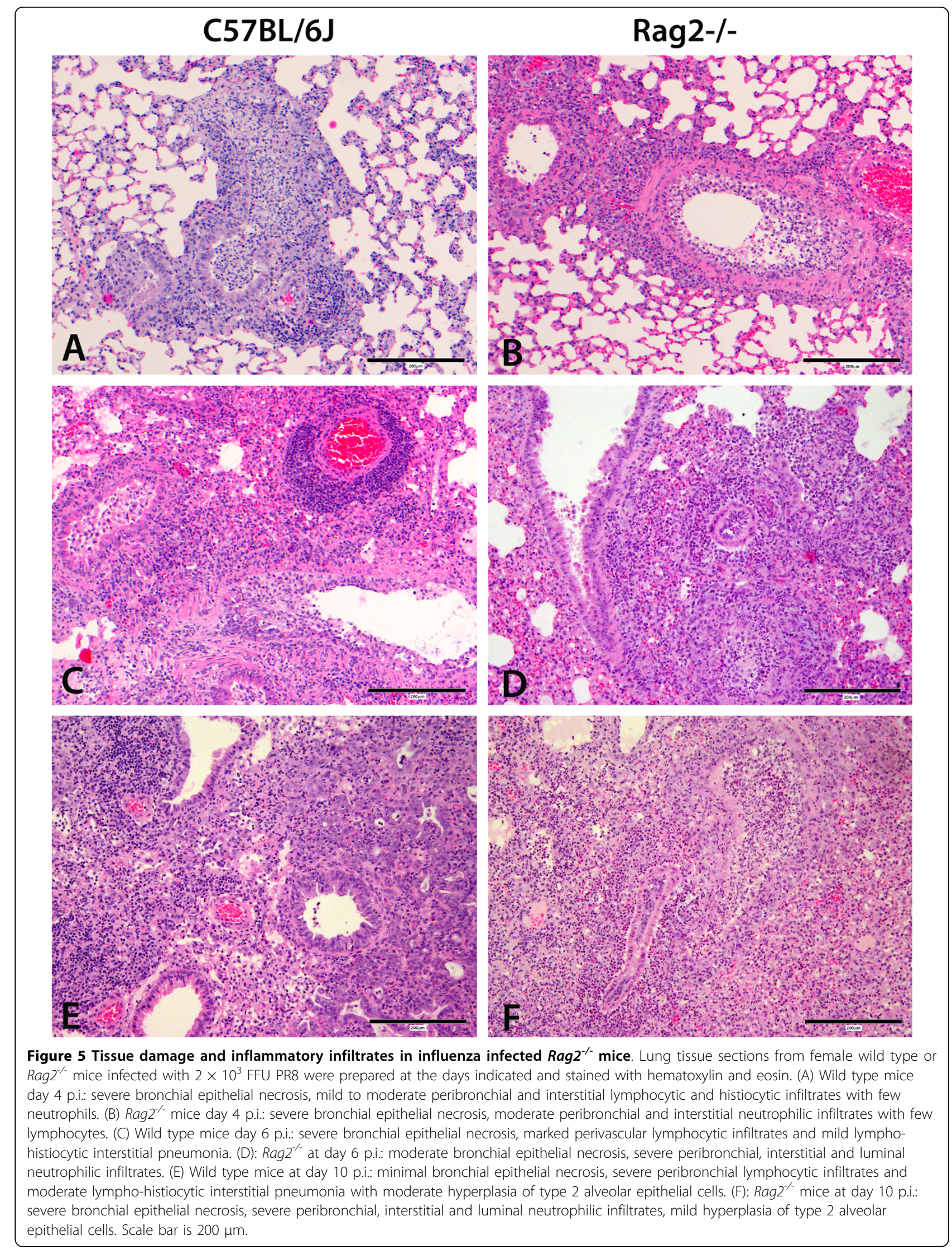


efficiently as in wild type mice to protect the host from lethal pathologies at early time points after infection. However, at later stages of infection the adaptive immune response which is necessary to clear the virus and protect the host from lethal pathological damage is missing in $\mathrm{Rag}^{-/-}$mice.

\section{Acknowledgements}

This work was supported by intra-mural funding from the HelmholtzAssociation (Program Infection and Immunity) and from research grants FluResearchNet (No. 01KI07137) and the Program for Medical Genome Research NGFNplus (No. 01GS0855) from the German Ministry of Education and Research to KS. HW has obtained a PhD fellowship from the HelmholtzChina Scholarship Council Exchange program. Mice for these experiments were maintained by the animal caretakers at the Central Animal Facilities at the HZl. We would like to thank Anna Rinkel for her excellent technical assistance of the histological studies. Also, we thank Victor Wray and Mahmoud Bahgat for critical reading of the manuscript.

\section{Author details}

${ }^{1}$ Department of Infection Genetics, Helmholtz Centre for Infection Research and University of Veterinary Medicine Hannover, Inhoffenstr. 7, D-38124 Braunschweig, Germany. ${ }^{2}$ Department of Pathology, University of Veterinary Medicine Hannover, Bünteweg 17, D-30559 Hannover, Germany.

\section{Authors' contributions}

HW conducted the study, analyzed the results, and contributed to writing of the manuscript. KS designed the study and wrote the manuscript. $\mathrm{VH}$ and WB performed the histo-pathological analyses and contributed to the writing of the manuscript. All authors read and approved the final manuscript.

\section{Competing interests}

The authors declare that they have no competing interests.

Received: 6 July 2010 Accepted: 28 July 2010 Published: 28 July 2010

\section{References}

1. Kohlmeier JE, Woodland DL: Immunity to respiratory viruses. Annu Rev Immunol 2009, 27:61-82.

2. Doherty PC, Topham DJ, Tripp RA, Cardin RD, Brooks JW, Stevenson PG: Effector CD4+ and CD8+ T-cell mechanisms in the control of respiratory virus infections. Immunol Rev 1997, 159:105-117.

3. Bender BS, Croghan T, Zhang L, Small PA Jr: Transgenic mice lacking class I major histocompatibility complex-restricted T cells have delayed viral clearance and increased mortality after influenza virus challenge. J Exp Med 1992, 175:1143-1145.

4. Allan W, Tabi Z, Cleary A, Doherty PC: Cellular events in the lymph node and lung of mice with influenza. Consequences of depleting CD4+ T cells. J Immunol 1990, 144:3980-3986.

5. Eichelberger M, Allan W, Zijlstra M, Jaenisch R, Doherty PC: Clearance of influenza virus respiratory infection in mice lacking class I major histocompatibility complex-restricted CD8+ T cells. J Exp Med 1991, 174:875-880

6. Graham MB, Braciale TJ: Resistance to and recovery from lethal influenza virus infection in B lymphocyte-deficient mice. J Exp Med 1997, 186:2063-2068.

7. Mozdzanowska K, Furchner M, Maiese K, Gerhard W: CD4+ T cells are ineffective in clearing a pulmonary infection with influenza type $A$ virus in the absence of B cells. Virology 1997, 239:217-225.

8. Topham DJ, Doherty PC: Clearance of an influenza A virus by CD4+ T cells is inefficient in the absence of B cells. J Virol 1998, 72:882-885.

9. Mozdzanowska K, Maiese K, Gerhard W: Th cell-deficient mice control influenza virus infection more effectively than Th- and B cell-deficient mice: evidence for a Th-independent contribution by $B$ cells to virus clearance. J Immunol 2000, 164:2635-2643.
10. Epstein SL, Lo CY, Misplon JA, Bennink JR: Mechanism of protective immunity against influenza virus infection in mice without antibodies. J Immunol 1998, 160:322-327.

11. Kris RM, Asofsky R, Evans CB, Small PA Jr: Protection and recovery in influenza virus-infected mice immunosuppressed with anti-lgM. J Immunol 1985, 134:1230-1235.

12. Lee BO, Rangel-Moreno J, Moyron-Quiroz JE, Hartson L, Makris M, Sprague F, Lund FE, Randall TD: CD4 T cell-independent antibody response promotes resolution of primary influenza infection and helps to prevent reinfection. J Immunol 2005, 175:5827-5838.

13. Bosma GC, Custer RP, Bosma MJ: A severe combined immunodeficiency mutation in the mouse. Nature 1983, 301:527-530.

14. Palladino G, Mozdzanowska K, Washko G, Gerhard W: Virus-neutralizing antibodies of immunoglobulin $\mathrm{G}$ (lgG) but not of $\lg \mathrm{M}$ or $\lg \mathrm{A}$ isotypes can cure influenza virus pneumonia in SCID mice. J Virol 1995, 69:2075-2081.

15. Mombaerts P, lacomini J, Johnson RS, Herrup K, Tonegawa S, Papaioannou VE: RAG-1-deficient mice have no mature $B$ and $T$ lymphocytes. Cell 1992, 68:869-877.

16. Shinkai $Y$, Rathbun G, Lam KP, Oltz EM, Stewart V, Mendelsohn M, Charron J, Datta M, Young F, Stall AM, et al: RAG-2-deficient mice lack mature lymphocytes owing to inability to initiate $V(D) J$ rearrangement. Cell 1992, 68:855-867.

17. Spanopoulou E, Roman CA, Corcoran LM, Schlissel MS, Silver DP, Nemazee D, Nussenzweig MC, Shinton SA, Hardy RR, Baltimore D: Functional immunoglobulin transgenes guide ordered B-cell differentiation in Rag-1-deficient mice. Genes Dev 1994, 8:1030-1042.

18. Jayasekera JP, Moseman EA, Carroll MC: Natural antibody and complement mediate neutralization of influenza virus in the absence of prior immunity. J Virol 2007, 81:3487-3494.

19. Bot A, Reichlin A, Isobe H, Bot S, Schulman J, Yokoyama WM, Bona CA: Cellular mechanisms involved in protection and recovery from influenza virus infection in immunodeficient mice. J Virol 1996, 70:5668-5672.

20. Srivastava B, Blazejewska P, Hessmann M, Bruder D, Geffers R, Mauel S, Gruber AD, Schughart K: Host genetic background strongly influences the response to influenza a virus infections. PLOS ONE 2009, 4:e4857.

21. Haines DM, Waters EH, Clark EG: Immunohistochemical detection of swine influenza A virus in formalin-fixed and paraffin-embedded tissues. Can J Vet Res 1993, 57:33-36.

doi:10.1186/1743-422X-7-172

Cite this article as: Wu et al:: Sustained viral load and late death in Rag2-/- mice after influenza A virus infection. Virology Journal 2010 7:172.

\section{Submit your next manuscript to BioMed Central and take full advantage of:}

- Convenient online submission

- Thorough peer review

- No space constraints or color figure charges

- Immediate publication on acceptance

- Inclusion in PubMed, CAS, Scopus and Google Scholar

- Research which is freely available for redistribution 